\title{
Occurrence and molecular characterization of Cryptosporidium sp. in sheep
}

\section{Ocorrência e caracterização molecular de Cryptosporidium sp. em ovinos}

\author{
Alessandra Snak ${ }^{1 *}$; Flavia Roberta Smiderle ${ }^{2}$; Nelson Luis Mello Fernandes ${ }^{3}$; \\ Arielle Aparecida Lara ${ }^{4}$; Felipe Gustavo Garcia²; \\ Liza Ogawa ${ }^{5}$; Silvia Cristina Osaki ${ }^{3}$
}

\begin{abstract}
Considered a zoonosis of utmost importance, cryptosporidiosis has a worldwide distribution and can infect mammals, birds, reptiles, and amphibians. It is caused by a highly resistant protozoan present in the environment and can cause death in immunosuppressed individuals and pups, as well as in farm animals such as cattle and sheep, generating losses. The aim of this study was to investigate the presence of Cryptosporidium spp. in sheep feces from the farms of Western Paraná, which have different management styles, and compare the results with their respective management methods. One hundred and forty-four stool samples were collected (69 from Property 1 and 75 from Property 2) and analyzed using a fecal smear on slides after staining by the modified Ziehl-Neelsen method. Samples tested positive by this method were subjected to nested PCR and the products obtained were sent for sequencing to determine the species. While $82.60 \%$ of the samples from Property 1 were tested positive, only $36 \%$ of the samples from Property 2 were tested positive. On analyzing the sequencing data, it was observed that the Cryptosporidium species of samples from Property 1 showed high similarity to Cryptosporidium xiaoi and those from Property 2, to Cryptosporidium ubiquitum. The reason for divergence in results can be attributed to differences in management systems adopted by each property, thus showing the importance of detecting carrier animals, as they can contaminate the environment, especially the water sources, and spread the disease to humans and other animals.
\end{abstract}

Key words: Cryptosporidium ubiquitum. Cryptosporidium xiaoi. Nested-PCR. Sheep. Ziehl-Neelsen.

\section{Resumo}

Considerada uma zoonose de extrema importância, a cryptosporidiose possui distribuição mundial e pode infectar mamíferos, aves, répteis e anfíbios. É causada por um protozoário muito resistente no ambiente, podendo gerar mortes em indivíduos imunossuprimidos e filhotes, principalmente em animais de produção como bovinos e ovinos, gerando prejuízos. O objetivo desse trabalho foi pesquisar a presença de Cryptosporidium spp. em fezes de ovinos de propriedades rurais do Oeste do Paraná, que possuem manejos diferenciados e comparar os resultados encontrados com o respectivo manejo.

\footnotetext{
${ }^{1}$ Discente de Doutorado em Ciência Animal, Universidade do Estado de Santa Catarina, UDESC, Lages, SC, Brasil. E-mail: alessandra.snak@hotmail.com

2 Discentes em Medicina Veterinária, Universidade Federal do Paraná, UFPR, Palotina, PR, Brasil. E-mail: flaviasmiderle@yahoo. com.br; felipedo402@gmail.com

3 Profs., Universidade Federal do Paraná, UFPR, Palotina, PR, Brasil. E-mail: nlmfernandes@gmail.com; silvia_cristinao@yahoo. com.br

${ }^{4}$ Discente de Mestrado em Ciência Animal, UFPR, Palotina, PR, Brasil. E-mail: ariellelara91@gmail.com

${ }^{5}$ Prof $^{a}$, Universidade Estadual do Norte do Paraná, UENP, Bandeirantes, PR, Brasil. E-mail: logawa@uenp.edu.br

* Author for correspondence
} 
Foram coletadas 144 amostras de fezes, sendo 69 da Propriedade 1 e 75 da Propriedade 2, analisadas pelo esfregaço de fezes em lâminas após a coloração pelo método de Ziehl-Neelsen modificado. As amostras positivas por esse método foram submetidas à Nested-PCR sendo os produtos obtidos enviados ao sequenciamento para a determinação da espécie. A Propriedade 1 apresentou positividade em $82,60 \%$ das amostras, enquanto a Propriedade 2 obteve $36 \%$ de amostras positivas. Foi encontrada alta similaridade para Cryptosporidium xiaoi na primeira propriedade e Cryptosporidium ubiquitum na segunda propriedade. A divergência nos resultados pode ser comprovada pela diferente forma de manejo adotada em cada propriedade, mostrando a importância de detectar os animais portadores, uma vez que estes podem contaminar o meio ambiente, especialmente os cursos d'água, e promover a disseminação da doença para outros animais e para o homem.

Palavras-chave: Cryptosporidium ubiquitum. Cryptosporidium xiaoi. Nested-PCR. Ovinos. Ziehlneelsen.

\section{Introduction}

Protozoa of the genus Cryptosporidium (Eucoccidiorida: Cryptosporiidae) are obligate intracellular parasites, affecting mainly the intestinal epithelial cells, but can also infect the urinary and respiratory tracts of the host (XIAO; FAYER, 2008). They usually cause enteric injury, leading to diarrhea due to bad absorption, which can be observed through the clinical signs of the diseasedehydration, abdominal pain, apathy, anorexia, and progressive weight loss (JERVIS et al., 1966; ODONOGHUE, 1995).

Diarrhea, the main symptom, is usually associated with individuals who are young, immunosuppressed, or both. In sheep, clinical signs are more common in animals between six and 28 days old (ORTEGAMORA; WRIGHT, 1994; MARTINEZ et al., 2001; QUILEZ et al., 2003).

Considered a zoonosis of utmost importance, cryptosporidiosis has a worldwide distribution and can infect about 170 species of animals including mammals, birds, reptiles, and amphibians (SANTÍN, 2013; XIAO; FAYER, 2008; BOUZID et al., 2013). Currently, about 26 species of Cryptosporidium spp. have been established (ICZN) and 40 genotypes that infect humans, animals, or both, described (RYAN et al., 2014; SLAPETA, 2013).

Cryptosporidiosis ranked fifth among the 24 most important parasites transmitted by food, in the global ranking published in 2012 by the Food and Agriculture Organization (FAO) and World Health
Organization (WHO) (FAO/WHO, 2014). The primary medium of transmission is through drinking contaminated water and proximity to humans and infected animals. Currently, the importance of this genus to human and animal health has been underestimated (RYAN et al., 2014).

\section{Material and Methods}

The Ethics and Animal Use Committee (EAUC), UFPR, Palotina, approved the project under the Protocol 14/2014.

One hundred and forty-four stool samples were collected directly from the rectum of sheep from two sheep farms in western Paraná-69 samples from Property 1 and 75 samples from Property 2 . Property 1 is located in the city of Cascavel, Paraná, Brazil, and has approximately 75 animals in semiextensive management. Property 2 is located in the city of Toledo (30 km away from Property 1) in the same state and has approximately 200 sheep, again in semi-extensive management.

The samples were placed in clean containers with screw caps, and labeled with the animal number, age, sex, and stool appearanceconsistency. The samples were kept refrigerated until processing, which occurred on the same day of collection.

In the laboratory, about $5 \mathrm{~g}$ of feces was diluted in $40 \mathrm{ml}$ of water and passed through a sieve gauze to remove the solid particles. Next, a small sample of the liquid was centrifuged for 2 minutes at 2,500 
rpm, and the supernatant discarded. Slides were prepared using the pellet.

After drying, modified Ziehl-Neelsen staining method was performed (ORTOLANI, 2000). The slides were examined under the oil immersion objective lens of a light microscope, with a total magnification of $1000 \mathrm{x}$.

Genomic DNA extraction and Polymerase Chain Reaction (PCR) were performed for the samples tested positive by the modified Ziehl-Neelsen method for Cryptosporidium spp.

The Macherey-nagel NucleoSpin Tissue commercial kit was used for genomic DNA extraction. Next, a double polymerase chain reaction (nested PCR) was performed, according to the protocol described by Macarisin et al. (2010), but without bovine serum albumin (BSA). The amplified products were visualized by electrophoresis on a $1.5 \%$ agarose gel.

Two samples were selected, one from each property, for sequencing the genetic material. The sequencing of the samples was carried out by ACTGene Analysis Molecular Ltda. (Biotechnology Center, UFRGS, Porto Alegre, RS) using the automated sequencer AB 3500 Genetic Analyzer, equipped with capillaries of $50 \mathrm{~cm}$ and POP7 polymer (Applied Biosystems).
The DNA templates were labeled using 2.5 pmol each of primers XIA2F and XIA2R (5'-GGAAGGGTTGTATTTATTAGATAAAG3'/5'-AAGGAGTAAGGAACAACCTCCA-3') and $0.5 \mu \mathrm{L}$ of the BigDye Terminator v3.1 Cycle Sequencing Standard reagent (Applied Biosystems) in a final volume of $10 \mu \mathrm{L}$. The labeling reactions were performed in a thermocycler LGC XP Cycler with an initial denaturation step at $96^{\circ} \mathrm{C}$ for $3 \mathrm{~min}$ followed by 25 cycles of $96^{\circ} \mathrm{C}$ for $10 \mathrm{~s}, 55^{\circ} \mathrm{C}$ for $5 \mathrm{~s}$, and $60^{\circ} \mathrm{C}$ for $4 \mathrm{~min}$. Once labeled, the samples were purified by precipitation with $75 \%$ isopropanol and washing with $60 \%$ ethanol. The precipitated products were diluted in $10 \mu \mathrm{L}$ of $\mathrm{Hi}$-Fi formamide (Applied Biosystems), denatured at $95^{\circ} \mathrm{C}$ for 5 $\mathrm{min}$, cooled on ice for $5 \mathrm{~min}$, and electro injected into an automated sequencer. The sequencing data were collected using the Data Collection 2 program (Applied Biosystems) with parameters Dye Set “Z”; Mobility File "KB_3500_POP7_BDTv3.mob"; BioLIMS Project "3500_Project1"; Run Module 1 "FastSeq50_POP7_50cm_cfv_100"; e Analysis Module 1 "BC-3500SR_Seq_FASTA.saz".

\section{Results and Discussion}

Of the 144 samples of sheep feces analyzed for Cryptosporidium spp., 85 were positive (Figure 1), which equals to a percentage of $59 \%$.

Figure 1. A) oocyst of Cryptosporidium spp. in blade sheep feces, stained by modified Ziehl-Neelsen method, increased 1000X; B) nested PCR positive for Cryptosporidium spp. 1: molecular size marker (1kb); 2: positive control; 3, 4 and 5: positive field samples; 6: Negative field sample; 7: negative control.

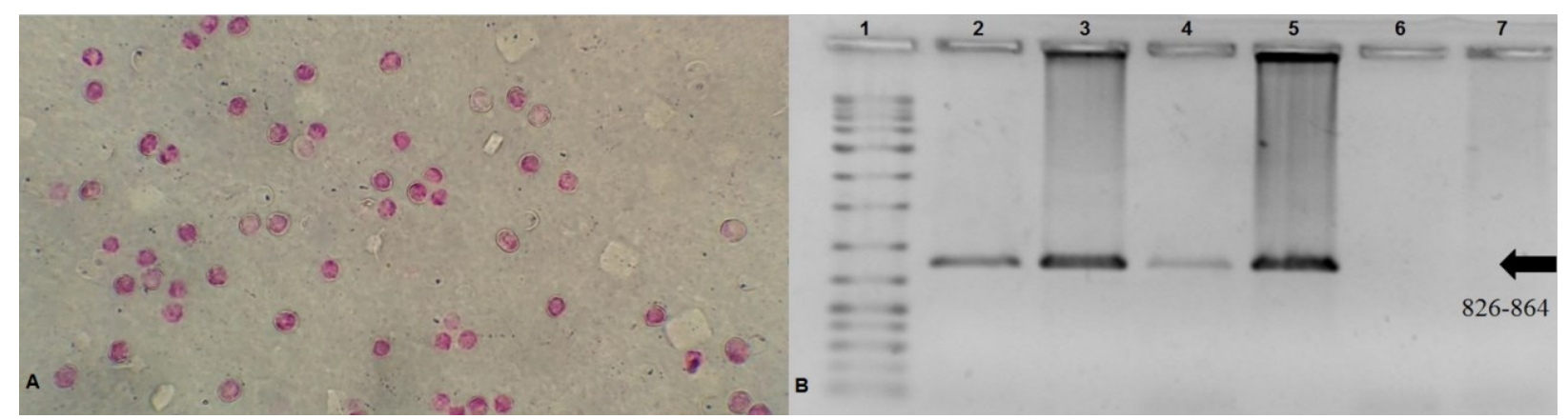


Samples were collected from two properties of same sheep production way and aim. In Property 1, $82.60 \%(57 / 69)$ of the samples were positive for the parasite, while Property 2 had a lower percentage of samples tested positive $-36 \%(27 / 75)$ - as shown in Table 1.

Table 1. Results of samples of feces in sheep for the diagnosis of Cryptosporidium spp.

\begin{tabular}{|c|c|c|c|c|c|c|}
\hline \multirow{2}{*}{\multicolumn{2}{|c|}{ Pasty }} & \multicolumn{2}{|c|}{ Positives } & \multicolumn{2}{|c|}{ Negatives } & \multirow{2}{*}{ Total } \\
\hline & & Normal & Pasty & Norm & & \\
\hline \multirow{2}{*}{ Property 1} & & 43 & 14 & 7 & 5 & \\
\hline & Total & & \multirow[b]{2}{*}{19} & \multicolumn{2}{|c|}{$12(17,39 \%)$} & 69 \\
\hline Property 2 & Total & 8 & & 6 & 42 & 75 \\
\hline
\end{tabular}

There was a significant difference in the results found when both properties were compared. This can be explained by the different management practices of the animals in the properties; although both use the semi-extensive system with grazing feeding and feed in the trough, there is a clear difference in hygiene, organization, and care for the animals. Additionally, in Property 2, the mother is separated from the lambs, unlike in Property 1, and this measure is important in controlling parasitic infections, especially cryptosporidiosis.

Martinez et al. (2001) also related the occurrence of the parasite in sheep with properties that have poor infrastructure, where they found that $87 \%$ of the lambs tested positive for the parasite.

The frequency of the parasite found in both the properties is higher than that reported by several authors such as Olson et al. (1997), Castro-Hermida et al. (2007), Silva (2009), Tembue et al. (2006), Féres et al. (2009), and Maurya et al. (2013). However, Property 1 showed a very high frequency when compared to those studies. Santín and Fayer (2007) found that $77.4 \%$ of the sheep from a farm in Maryland were positive for Cryptosporidium spp., a percentage similar to the one found at Property 1, indicating the easy transmission of the parasite in precarious hygiene conditions.

The fecal samples were classified by their consistency, divided into pasty and normal stool; none of the samples showed a diarrheal aspect. Out of the 84 positive samples, $60.71 \%$ showed pasty consistency. Causapé et al. (2002), Zucatto et al. (2015) also found a higher percentage of Cryptosporidium in pasty feces of sheep.

As there were few samples collected from males (5/69 and 0/75) and lambs (7/69 and 0/75), these data are irrelevant to the research. However, there are many adult females releasing the parasite's oocysts into the environment, without showing clinical signs. These are potential disseminators of the disease among animals, especially to the young, as in the case of Property 1, as well as among humans. Several authors support this finding, making it necessary to separate the animals in maternity (SMITH et al., 2010; ORTEGA-MORA; WRIGHT, 1994).

After sequencing the samples, it was possible to identify different species circulating in each of the properties. The species from Property 1 showed high similarity to $C$. xiaoi and those from Property 2, to C. ubiquitum. Since only one sample from each property was sequenced in this study, it cannot be concluded that this is the only species of Cryptosporidium parasitizing the animals, and other species of the protozoa may be circulating in the environment. There are several species of Cryptosporidium that parasitize sheep, but the most prevalent are C. xiaoi, C. ubiquitum, and $C$. 
parvum; the first is commonly found in Australia; the second, in America and Asia; and the third, in Europe (RYAN et al., 2014; YE et al., 2013).

C. xiaoi was first described in sheep in 2009 (FAYER; SANTIN, 2009). Previously, it was known as C. bovis-like and was found in sheep in the United States (SANTÍN et al., 2007), Spain (NAVARRO-I-MARTINEZ et al., 2007), Tunisia (ELWIN; CHALMERS, 2008), United Kingdom (MUELLER-DOBLIES et al., 2008), China (WANG et al., 2010; YE et al., 2013), Norway (ROBERTSON et al., 2010), Australia (SWEENY et al., 2011), and Egypt (MAHFOUZ et al., 2014). In Brazil, the first report of this parasite in sheep was recorded in São Paulo in 2015, where it was found infecting 5- to 360-day-old sheep (ZUCATTO et al., 2015). In this study, the protozoa were found in adult sheep of approximately 3 years of age.

The first report of $C$. xiaoi in humans was in patients with HIV/AIDS in Ethiopia (ADAMU et al., 2014), where sheep may have been an important source for spreading this parasite to the human population; there is constant and periodic contact of feeders with the animals and possible sources of disease transmission such as water and food.

C. ubiquitum has the largest number of hosts among the Cryptosporidium species (FAYER et al., 2010). It was detected in sheep in Australia (SWEENY et al., 2011; RYAN et al., 2005; YANG et al., 2009), United States (SANTÍN; FAYER, 2007; SANTIN et al., 2007), Belgium (GEURDEN et al., 2008), China (WANG et al., 2010), Spain (DIAZ et al., 2010), Norway (ROBERTSON et al., 2010), UK (ELWIN; CHALMERS, 2008; MUELLERDOBLIES et al., 2008), and other countries. In Brazil, this species of Cryptosporidium has been detected by Fiuza et al. (2011) in the State of Rio de Janeiro and by Silva et al. (2014) and Zucatto et al. (2015) in São Paulo. Zucatto et al. (2015) found this species in 5to 180-day-old sheep, however in this study it was found in a sheep approximately 2.5 years old.

Recently, sheep have also been implicated as a potential source of infection of C. ubiquitum in humans (LI et al., 2014). Cases of human infection have been reported in Canada (ONG et al., 2002; WONG; ONG, 2006; TROTZ-WILLIAMS et al., 2006), New Zealand (LEARMONTH et al., 2004), United States (FELTUS et al., 2006; BLACKBURN et al., 2006), United Kingdom (LEONI et al., 2006; CHALMERS et al., 2009), and Slovenia (SOBA et al., 2006), among others. The lack of specificity and habitat probably contribute to the widespread distribution of the parasite; the protozoan is routinely found in clear waters, and several animal species release oocysts into the environment (JIANG et al., 2005).

As there was a high percentage of animals positive for the parasite and considering that Cryptosporidium is a parasite that is not constantly eliminated, this percentage may be even higher; hence, preventive measures should be adopted in both properties to prevent contamination of new animals and human beings. Basic measures should be taken for improving sanitation in the facilities, bettering water treatment, and separating female sheep in pre-natal and maternity stage from the lambs.

\section{Conclusion}

A high percentage of Cryptosporidium sp. was found in sheep from both properties, but Property 1 had a higher percentage of infected sheep, suggesting that sanitary and preventive measures should be adopted to prevent the spread of the parasite. The presence of $C$. xiaoi was detected in Property 1 and C. ubiquitum, in Property 2.

\section{References}

ADAMU, H.; PETROS, B.; ZHANG, G.; KASSA, H.; AMER, S.; YE, J.; FENG, Y.; XIAO, L. Distribution and clinical manifestations of Cryptosporidium species and subtypes in HIV/AIDS patients in Ethiopia. PLOS Neglected Tropical Disease, San Francisco, v. 8, n. 4, e2831, p. 1-10, 2014.

BLACKBURN, B. G.; MAZUREK, J. M.; HLAVSA, M.; PARK, J.; TILLAPAW, M.; PARRISH, M.; SALEHI, 
E.; FRANKS, W.; KOCH, E.; SMITH, F.; XIAO, L.; ARROWOOD, M.; HILL, V.; SILVA, A. da; JOHNSTON, S.; JONES, J. L. Cryptosporidiosis associated with ozonated apple cider. Emerging Infectious Diseases, Foster, v. 12, n. 4, p. 684-686, 2006.

BOUZID, M.; HUNTER, P. R.; CHALMERS, R. M.; TYLER, K. M. Cryptosporidium pathogenicity and virulence. Clinical Microbiology Review, Washington, v. 26, n. 1, p. 115-134, 2013.

CASTRO-HERMIDA, J. A.; ALMEIDA, A.; GONZÁLEZ-WARLETA, M.; COSTA, J. M. C.; RUMBO-LORENZO, C.; MEZO, M. Occurrence of Cryptosporidium parvum and Giardia duodenalis in healthy adult domestic ruminants. Parasitology Research, Berlin, v. 101, n. 5, p. 1443-1448, 2007.

CAUSAPÉ, A. C.; QUILEZ, J.; SANCHEZ-ACEDO, C. Prevalence and analysis of potential risk factors for Cryptosporidium parvum infection in lambs in Zaragoza (northeastern Spain). Veterinary Parasitolology, Amsterdam, v. 104, n. 4, p. 287-298, 2002.

CHALMERS, R. M.; ELWIN, K.; THOMAS, A. L.; GUY, E. C.; MASON, B. Long-term Cryptosporidium typing reveals the aetiology and speciesspecific epidemiology of human cryptosporidiosis in England and Wales, 2000 to 2003. Euro Surveillnce, Stockholm, v. 14, n. 2, p. 1-9, 2009.

DIAZ, P.; QUILEZ, J.; CHALMERS, R. M.; PANADERO, R.; LOPEZ, C.; MORRONDO, P.; DIEZBANOS, P.; SANCHEZ-ACEDO, C. Genotype and subtype analysis of Cryptosporidium isolates from calves and lambs in Galicia (NW Spain). Parasitology, London, v. 137, n. 8, p. 1187-1193, 2010.

ELWIN, K.; CHALMERS, R. M. Contemporary identification of previously reported novel Cryptosporidium isolates reveals Cryptosporidium bovis and the cervine genotype in sheep (Ovis aries). Parasitology Research, Berlin, v. 102, n. 5, p. 1103-1105, 2008.

FOOD AND AGRICULTURE ORGANIZATION OF THE UNITED NATIONS/WORLD HEALTH ORGANIZATION - FAO/WHO. Multicriteria-based ranking for risk management of food-borne parasites. Rome: FAO, 2014. 302 p. (Microbiological Risk Assessment Series, n. 23).

FAYER, R.; SANTIN, M. Cryptosporidium xiaoi n. sp. (Apicomplexa: Cryptosporidiidae) in sheep (Ovis aries). Veterinary Parasitology, Amsterdam, v. 164, n. 2-4, p. 192-200, 2009.
FAYER, R.; SANTIN, M.; MACARASIN, D. Cryptosporidium ubiquitum $\mathrm{n}$. sp. in animals and humans. Veterinary Parasitology, Amsterdam, v. 172, n. 1-2, p. 23-32, 2010.

FELTUS, D. C.; GIDDINGS, C. W.; SCHNECK, B. L.; MONSON, T.; WARSHAUER, D.; MCEVOY, J. M. Evidence supporting zoonotic transmission of Cryptosporidium in Wisconsin. Journal of Clinical Microbiology, Washington, v. 44, n. 12, p. 4303-4308, 2006.

FÉRES, F. C.; LOMBARDI, A. L.; CARVALHO, M. P. P.; MENDES, L. C. N.; PEIRÓ, J. R.; CADIOLI, F. A.; MEIRELES, M. V.; PERRI, S. H. V.; FEITOSA, F. L. F. Ocorrência e caracterização molecular de Cryptosporidium em cordeiros. Arquivo Brasileiro de Medicina Veterinária e Zootecnia, Belo Horizonte, v. 6, n. 4, p. 1002-1005, 2009.

FIUZA, V. R. S.; COSENDEV, R. I. J.; TEIXEIRA, E. F.; SANTIN, M.; FAYER, R.; OLIVEIRA, F. C. R. Molecular characterization of Cryptosporidium in Brazilian sheep. Veterinary Parasitology, Amsterdam, v. 175, n. 3-4, p. 360-362, 2011.

GEURDEN, T.; THOMAS, P.; CASAERT, S.; VERCRUYSSE, J.; CLAEREBOUT, E. Prevalence and molecular characterisation of Cryptosporidium and Giardia in lambs and goat kids in Belgium. Veterinary Parasitology, v. 155, n. 1-2, p. 142-145, 2008.

JERVIS, H. R.; MERRIL, J. G.; SPRINZ, H. Coccidiosis in the guinea pig small intestine due a Cryptosporidium. American Journal of Veterinary Research, Chicago, v. 27, n. 117, p. 408-414, 1966.

JIANG, J.; ALDERISIO, K. A.; XIAO, L. Distribution of Cryptosporidium genotypes in storm event water samples from three watersheds in New York. Applied and Environmental Microbiology, Washington, v. 71, n. 8, p. 4446-4454, 2005.

LEARMONTH, J. J.; IONAS, G.; EBBETT, K. A.; KWAN, E. S. Genetic characterization and transmission cycles of Cryptosporidium species isolated from humans in New Zealand. Applied and Environmental Microbiology, Washington, v. 70, n. 7, p. 3973-3978, 2004.

LEONI, F.; AMAR, C.; NICHOLS, G.; PEDRAZADIAZ, S.; MCLAUCHLIN, J. Genetic análisis of Cryptosporidium from 2414 human with diarrea in England between 1985 and 2000. Journal of Medical Microbiology, London, v. 55, n. 6, p. 703-707, 2006. 
LI, N.; XIAO, L.; ALDERISIO, K.; ELWIN, K.; CEBELINSKI, E.; CHALMERS, R.; SANTIN, M.; FAYER, R.; KVAC, M.; RYAN, U.; SAK, B.; STANKO, M.; GUO, Y.; WANG, L.; ZHANG, L.; CAI, J.; ROELLIG, D.; FENG, Y. Subtyping Cryptosporidium ubiquitum, a zoonotic pathogen emerging in humans. Emerging Infectious Disease, Oxford, v. 20, n. 2, p. 217224, 2014.

MACARISIN, D.; SANTIN, M.; BAUCHAN, G.; FAYER, R. Infectivity of Cryptosporidium parvum oocysts after storage of experimentally contaminated apples. Journal of Food Protection, Ames, v. 73, n. 10, p. 1824-1829, 2010.

MAHFOUZ, M. E.; MIRA, N.; AMER, S. Prevalence and genotyping of Cryptosporidium spp. In farm animals in Egypt. Journal of Veterinary Medicine Science, Oxford, v. 76, n. 12, p. 1569-1575, 2014.

MARTINEZ, R. D. R.; PRIETO, R. H. P.; VERA, E. La Cryptosporidiosis en los terneros recien nacidos. $\mathrm{Su}$ etiologia, patogenia, sintomas, tratamiento y profilaxia. Revista de Ciencia y Tecnologia, Misiones, v. 1, n. 1, p. 99-108, 2001.

MAURYA, P. S.; RAKESH, R. L.; PRADEEP, B.; KUMAR, S.; KUNDU, K.; GARG, R.; RAM, H.; KUMAR, A.; BANERJEE, P. S. Prevalence and risk factors associated with Cryptosporidium spp. infection in young domestic livestock in India. Tropical Animal Health and Production, Edinburgh, v. 45, n. 4, p. 941946, 2013.

MUELLER-DOBLIES, D.; GILES, M.; ELWIN, K.; SMITH, R. P.; CLIFTON-HADLEY, F. A.; CHALMERS, R. M. Distribution of Cryptosporidium species in sheep in the UK. Veterinary Parasitology, Amsterdam, v. 154, n. 3-4, p. 214-219, 2008.

NAVARRO-I-MARTINEZ, L.; SILVA, A. J. da; BORNAY-LLINARES, F. J.; MOURA, I. N.; DEL AGUILA, C.; OLEAGA,A.; PIENIAZEK, N. J. Detection and molecular characterization of Cryptosporidium bovis-like isolate from a newborn lamb in Spain. The Journal of Parasitology, Lawrence, v. 93, n. 6, p. 15361538, 2007.

ODONOGHUE, P. J. Cryptosporidium and cryptosporidiosis in man and animal. International Journal of Parasitology, Oxford, v. 25, n. 2, p. 139-195, 1995.

OLSON, M. E.; THORLAKSON, C. L.; DESELLIERS, L.; MORCK, D. W.; MCALLISTER, T. A. Giardia and Cryptosporidium in Canadian farm animals. Veterinary Parasitology, Amsterdam, v. 68, n. 4, p. 375-381, 1997.
ONG, C. S. L.; EISLER, D. L.; ALIKHANI, A.; FUNG, V. W.; TOMLIN, J.; BOWIE, W. R.; ISAAC-RENTON, J. L. Novel Cryptosporidium genotypes in sporadic cryptosporidiosis cases: first report of human infections with a cervine genotype. Emerging Infectious Diseases, Atlanta, v. 8, n. 3, p. 263-268, 2002.

ORTEGA-MORA, L. M.; WRIGHT, S. E. Age-related resistance in ovine cryptosporidiosis: patterns of infection and humoral immune response. Infection and Immunity, Washington, v. 62, n. 11, p. 5003-5009, 1994.

ORTOLANI, E. L. Standardization of the modified ZiehlNeelsen technique to stain oocysts of Cryptosporidium sp. Revista Brasileira de Parasitologia Veterinária, Jaboticabal, v. 9, n. 1, p. 29-31, 2000.

QUILEZ, J.; ACEDO, C. S.; CACHO, E. Criptosporidioses de los pequenos ruminantes. Pequenos Ruminantes, Cordoba, v. 4, n. 2, p. 1-20, 2003.

ROBERTSON, L. J.; GJERDE, B. K.; FURUSETH HANSEN, E. The zoonotic potential of Giardia and Cryptosporidium in Norwegian sheep: a longitudinal investigation of 6 flocks of lambs. Veterinary Parasitology, Amsterdam, v. 171, n. 1-2, p. 40-145, 2010.

RYAN, U.; FAYER, R.; XIAO, L. Cryptosporidium species in humans and animals: current understanding and research needs. Parasitology, London, v. 141, n. 13, p. 1667-1685, 2014.

RYAN, U.; READ, C.; HAWKINS, P.; WARNECKE, M.; SWANSON, P.; GRIFFITH, M.; DEERE, D.; CUNNINGHAM, M.; COX, P. Genotypes of Cryptosporidium from Sydney water catchment areas. Journal of Applied Microbiology, Oxford, v. 98, n. 5, p. 1221-1229, 2005.

SANTÍN, M. Clinical and subclinical infections with Cryptosporidium in animals. New Zealand Veterinary Journal, Abingdon, v. 61, n. 1, p. 1-10, 2013.

SANTÍN, M.; FAYER, R. Intragenotypic variations in the Cryptosporidium sp. cervine genotype from sheep with implications for public health. The Journal of Parasitolology, Lawrence, v. 93, n. 3, p. 668-672, 2007.

SANTÍN, M.; TROUT, J. M.; FAYER, R. Prevalence and molecular characterization of Cryptosporidium and Giardia species and genotypes in sheep in Maryland. Veterinary Parasitology, Amsterdam, v. 146, n. 1-2, p. 17-24, 2007.

SILVA, F. M. P.; LOPES, R. S.; BRESCIANI, K. D. S.; AMARANTE, A. F. T.; ARAUJO, J. P. High occurrence of Cryptosporidium ubiquitum and Giardia duodenalis genotype E in sheep from Brazil. Acta Parasitologica, Warszawa, v. 59, n. 1, p. 193-196, 2014. 
SILVA, R. M. Infecção natural por Eimeria spp., Cryptosporidium spp. e Giardia duodenalis em cordeiros da raça mestiça Santa Inês, na região semi-árida do Estado do Rio Grande do Norte. 2009. Dissertação (Mestrado em Parasitologia) - Universidade Federal de Minas Gerais, Belo Horizonte.

SLAPETA, J. Cryptosporidiosis and Cryptosporidium species in animals and humans: A thirty colour rainbow? International Journal for Parasitology, Oxford, v. 43, n. 12-13, p. 957-970, 2013.

SMITH, R. P.; CHALMERS, R. M.; MUELLERDOBLIES, D.; CLIFTON-HADLEY, F. A.; ELWIN, K.; WATKINS, J.; PAIBA, G. A.; HADFIELD, S. J.; GILES, M. Investigation of farms linked to human patients with cryptosporidiosis in England and Wales. Preventive Veterinary Medicine, Amsterdam, v. 94, n. 1-2, p. 9-17, 2010.

SOBA, B.; PETOVEC, M.; MIOC, V.; LOGAR, J. Molecular characterisation of Cryptosporidium isolates from humans in Slovenia. Clinical Microbiolology and Infectious, Paris, v. 12, n. 9, p. 918-921, 2006.

SWEENY, J. P.; RYAN, U. M.; ROBERTSON, I. D.; YANG, R.; BELL, K.; JACOBSON, C. Longitudinal investigation of protozoan parasites in meat lamb farms in southern Western Australia. Preventive Veterinary Medicine, Amsterdam, v. 101, n. 3-4, p. 192-203, 2011.

TEMBUE, A. A. M.; ALVES, L. C.; BORGES, J. C. G.; FAUSTINO, M. A. G.; MACHADO, E. L. C. Ocorrência de Cryptosporidium spp. em ovinos no município de Ibimirim, estado de Pernambuco. Ciência Veterinária nos Trópicos, Recife, v. 9, n. 1, p. 41-43, 2006.
TROTZ-WILLIAMS, L. A.; MARTIN, D. S.; GATEI, W.; CAMA, V.; PEREGRINE, A. S.; MARTIN, S. W.; NYDAM, D. V.; JAMIESON, F.; XIAO, L. Genotype and subtype analyses of Cryptosporidium isolates from dairy calves and humans in Ontario. Parasitology Research, Berlin, v. 99, n. 4, p. 346-352, 2006.

WANG, Y.; FENG, Y.; CUI, B.; JIAN, F.; NING, C.; WANG, R.; ZHANG, L.; XIAO, L. Cervine genotype is the major Cryptosporidium genotype in sheep in China. Parasitology Research, Berlin, v. 106, n. 2, p. 341-347, 2010.

WONG, P. H. P.; ONG, C. S. L. Molecular characterization of the Cryptosporidium cervine genotype. Parasitology, London, v. 133, n. 6, p. 693-700, 2006.

XIAO, L.; FAYER, R. Molecular characterization of species and genotypes of Cryptosporidium and Giardia and assessment of zoonotic transmission. International Journal for Parasitology, Oxford, v. 38, n. 11, p. 12391255, 2008.

ZUCATTO, A. S.; AQUINO, M. C. C.; INÁCIO, S. V.; FIGUEIREDO, R. N.; PIERUCCI, J. C.; PERRI, S. H. V.; MEIRELES, M. V.; BRESCIANI, K. D. S. Molecular characterisation of Cryptosporidium spp. in lambs in the South Central region of the State of São Paulo. Arquivo Brasileiro de Medicina Veterinária e Zootecnia, Belo Horizonte, v. 67, n. 2, p. 441-446, 2015.

YANG, R.; JACOBSON, C.; GORDON, C.; RYAN, U. Prevalence and molecular characterization of Cryptosporidium and Giardia species in preweaned sheep in Australia. Veterinary Parasitology, Amsterdam, v. 16, n. 1-2, p. 19-24, 2009.

YE, J.; XIAO, L.; WANG, Y.; WANG, L.; AMER, S.; ROELLIG, D. M.; GUO, Y.; FENG, Y. Periparturient transmission of Cryptosporidium xiaoi from ewes to lambs. Veterinary Parasitology, Amsterdam, v. 197, n. 3-4, p. 627-633, 2013. 